TITLE:

Calanoid Copepods Collected from the Near-bottom in Tanabe Bay on the Pacific Coast of the Middle Honshu, Japan. III. Stephidae

$\operatorname{AUTHOR}(\mathrm{S})$ :

Ohtsuka, Susumu; Hiromi, Juro

CITATION:

Ohtsuka, Susumu ...[et al]. Calanoid Copepods Collected from the Near-bottom in

Tanabe Bay on the Pacific Coast of the Middle Honshu, Japan. III. Stephidae.

PUBLICATIONS OF THE SETO MARINE BIOLOGICAL LABORATORY 1987, 32(4-6): 219-232

ISSUE DATE:

$1987-12-26$

URL:

http://hdl.handle.net/2433/176144

RIGHT: 


\title{
Calanoid Copepods Collected from the Near-bottom in Tanabe Bay on the Pacific Coast of the Middle Honshu, Japan. III. Stephidae.
}

\author{
By \\ Susumu Ohtsuka \\ Faculty of Applied Biological Science, Hiroshima University, \\ Fukuyama, Hiroshima 720, Japan \\ and \\ Juro Hiromi \\ Faculty of Agriculture and Veterinary Medicine, Nihon University, \\ Shimouma, Setagaya, Tokyo 154, Japan \\ With Text-figures $1-9$ and Tables $1-2$ \\ The present paper deals with the description of two new species of Stephos (Family \\ Sampling area, bottom topography, gears and laboratory procedures were already described in \\ previous papers (Ohtsuka, 1984, 1985). Techniques for LM and SEM examinations of gut contents
} Stephidae) with a note on the in situ feeding habits of one of them. were presented in Ohtsuka et al. (1987).

\section{Stephos pacificus n. sp.}

(Figs 1-5)

Materials examined. An adult female dissected was designated as the holotype. An adult female and two males dissected and two intact adult females and males were designated as paratypes. The type specimens are deposited in the Seto Marine Biological Laboratory of Kyoto University.

Type locality: All the type specimens of this new species were collected from Tanabe Bay (23III-1983, day and night; 6.0-7.2 $\mathrm{m}$ in depth).

Female (holotype). Body (Fig. 1-A, B): $0.73 \mathrm{~mm}$ in length. Cephalosome separated from 1st metasomal segment; 4th and 5th metasomal segments partially fused. Posterolateral corners of prosome symmetrical, extending to one-fourth the length of genital segment. Urosome 4-segmented; genital segment (Fig. 1-C) produced ventrally, both sides with a curved row of minute spinules; 2nd and 3rd segments furnished with dense rows of spinules along distal margin; anal segment small. Spermatophore attached to genital segment, sausage-shaped, reaching beyond caudal rami. Caudal ramus slightly longer than broad, with fine hairs along inner margin and a minute setule near outer distal margin. Antennule (Fig. 1-D) 24-segmented, 
1st and 2nd segments partially fused; 1st to 10th segments except for 4th segment with minute spinules; 12th to 23rd segments each with a small lamellar plate. Antenna (Fig. 1-E) with 6-segmented exopod and 2-segmented endopod; proximal segment of endopod bearing two closely set setae on inner margin, and apical endopod segment with 6 setae apically and 7 setae of unequal lengths on a stepped

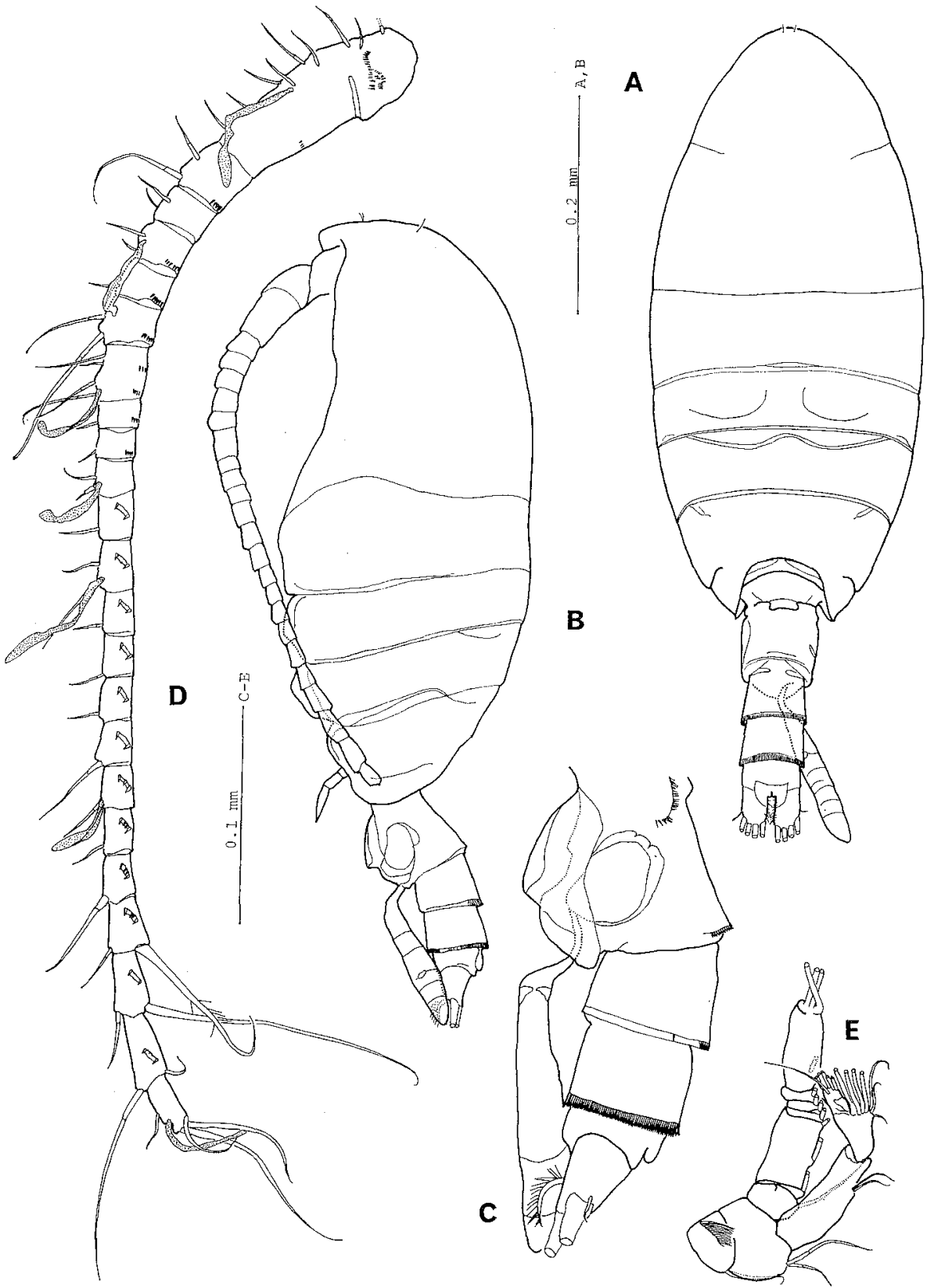

Fig. 1. Stephos pacificus n. sp. Female (holotype). A. Habitus, dorsal view; B. Habitus, lateral view; C. Urosome, lateral view; D. Antennule; E. Antenna. 
inner edge. Mandible (Fig. 2-A): cutting edge bearing 8 cuspidate teeth; basipod bearing 4 setae of unequal lengths along inner margin; endopod bearing 4 subterminal setae on proximal segment and 11 setae on apical segment; exopod 5-segmented. Maxillule (Fig. 2-B) well developed; gnathobase (1st inner lobe) with 6 spines and
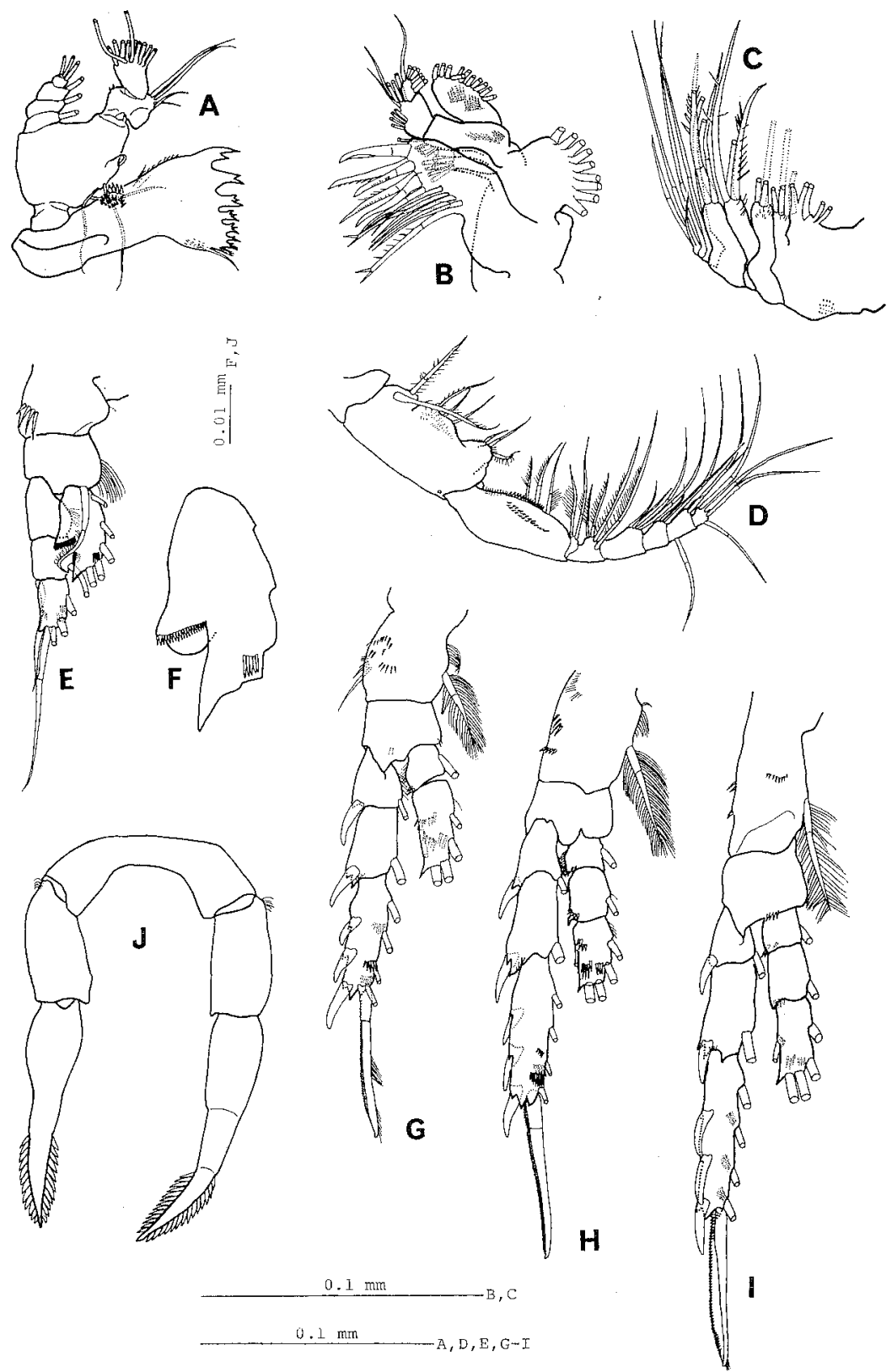

Fig. 2. Stephos pacificus n. sp. Female (holotype). A. Mandible; B. Maxillule; C. Maxilla; D. Maxilliped; E. Leg 1, anterior face; F. Endopod of leg 1: G. Leg 2, posterior face; H. Leg 3, anterior face; I. Leg 4, posterior face; J. Leg 5, posterior face. 
Table 1. Seta and spine formula of legs 1-4 of Stephos pacificus n. sp. Setae are represented by Arabic and spines by Roman numerals.

$\mathrm{Si}=$ inner border of segment; $\mathrm{St}=$ terminal border of segment; $\mathrm{Se}=$ outer border of segment.

\begin{tabular}{|c|c|c|c|c|c|c|c|c|c|c|c|c|c|c|c|c|c|c|c|c|}
\hline & \multicolumn{4}{|c|}{ Basipod } & \multicolumn{9}{|c|}{ Endopod } & \multicolumn{7}{|c|}{ Exopod } \\
\hline & \multicolumn{2}{|c|}{1} & \multicolumn{2}{|c|}{2} & \multicolumn{3}{|c|}{1} & \multicolumn{3}{|c|}{2} & \multicolumn{3}{|c|}{3} & \multicolumn{2}{|c|}{1} & \multicolumn{3}{|c|}{2} & \multicolumn{2}{|c|}{3} \\
\hline & $\mathrm{Si}$ & $\mathrm{Se}$ & $\mathrm{Si}$ & $\mathrm{Se}$ & $\mathrm{Si}$ & $\mathrm{St}$ & $\mathrm{Se}$ & $\mathrm{Si}$ & $\mathrm{St}$ & $\mathrm{Se}$ & $\mathrm{Si}$ & St & $\mathrm{Se}$ & $\mathrm{Si}$ & $\mathrm{Se}$ & $\mathrm{Si}$ & $\mathrm{Se}$ & $\mathrm{Si}$ & $\mathrm{St}$ & $\mathrm{Se}$ \\
\hline Leg 1 & 0 & 0 & 1 & 0 & 3 & 2 & 0 & - & - & - & - & - & - & 0 & 0 & 1 & I & 3 & 1 & $\mathrm{I}$ \\
\hline Leg 2 & 1 & 0 & 0 & 0 & 1 & - & 0 & 2 & 2 & 1 & - & - & - & 1 & I & 1 & I & 4 & I & III \\
\hline Leg 3 & 1 & 0 & 0 & 0 & 1 & 一 & 0 & 1 & - & 0 & 2. & 2 & 1 & 1 & I & 1 & I & 4 & I & III \\
\hline Leg 4 & 1 & 0 & 0 & 0 & 1 & - & 0 & 1 & - & 0 & 2 & 2 & 1 & 1 & I & 1 & I & 4 & $I$ & III \\
\hline
\end{tabular}

7 setae; 2nd and 3rd inner lobes bearing 3 and 4 setae, respectively; basipod 2 with a row of minute spinules longitudinally and 5 setae on inner distal end; exopod with two rows of fine spinules and 11 plumose setae distally; endopod 2-segmented, proximal segment bearing 9 setae and apical segment with 7 setae. Maxilla (Fig. $2-\mathrm{C}): 1$ st to 6 th inner lobes bearing $6,3,3,3,4$ and 1 setae, respectively; 4 th and 5th inner lobes each with stout spiniform seta. Maxilliped (Fig. 2-D): basipod 2 bearing 3 setae on middle part and a row of short spinules on the base. Setation and spinulation of legs are shown in Table 1. Leg 1 (Fig. 2-E, F): 1-segmented endopod and 3-segmented exopod; basipod 1 bearing long spinules near the middle of outer margin; rostro-lateral tubercle of endopod having a transverse row of fine spinules, and a row of minute spinules present at base of subterminal seta. Leg 2 (Fig. 2-G) : 2-segmented endopod and 3-segmented exopod; basipod 1 bearing long spinule and a patch of minute spinules near outer margin; terminal segments of endopod and exopod each having 3 rows of minute spinules on surface. Legs 3 and 4 (Fig. 2-H, I) : both endopod and expood 3-segmented with the same setation and spinulation characteristics; leg 4 longer than leg 3. Leg 5 (Fig. 2-J): both legs nearly symmetrical, uniramous and 3-segmented; right and left proximal segments fused medially; 2nd segment or basipod 2 bearing a tuft of fine hairs on outer proximal margin; terminal segment pointed, distal two-fifths of the segment with a finely serrated fringe on both sides. There are two weak transverse lines, each located at levels of distal two-fifths and three-fifths of the right terminal segment.

Male (paratype No. 1). Body (Fig. 3-A, B): $0.62 \mathrm{~mm}$ in length, smaller and slenderer than female; posterolateral corners of prosome slightly asymmetrical due to an extention of left distal corner. Urosome (Fig. 3-C, D) 5-segmented; 1st urosomal segment asymmetrical, swollen on left side; 2nd urosomal segment produced posteroventrally into short process, and furnished with a row of spinules along dorsodistal margin; posterior margins of $3 \mathrm{rd}$ and 4 th urosomal segments striated. Antennule (Fig. 3-E) : a very large aesthetasc present on 1st segment. Leg 5 (Fig. 3-F) with 4-segmented right leg and 5-segmented left leg. Right leg: 2nd segment bearing a spinular row along inner distal margin, 3rd segment much elongated with basal one-fourth expanded outwards and producing into an acute process, and last 
segment curved inwards, bordered by low lamella. Left leg: 2nd segment with a blunt prominence on inner edge medially, 4th segment not tumid but elongated with as pinular row on outer margin and a patch of very minute spinules near inner distal margin, and last segment with 3 terminal and 2 subterminal lamellar spines.
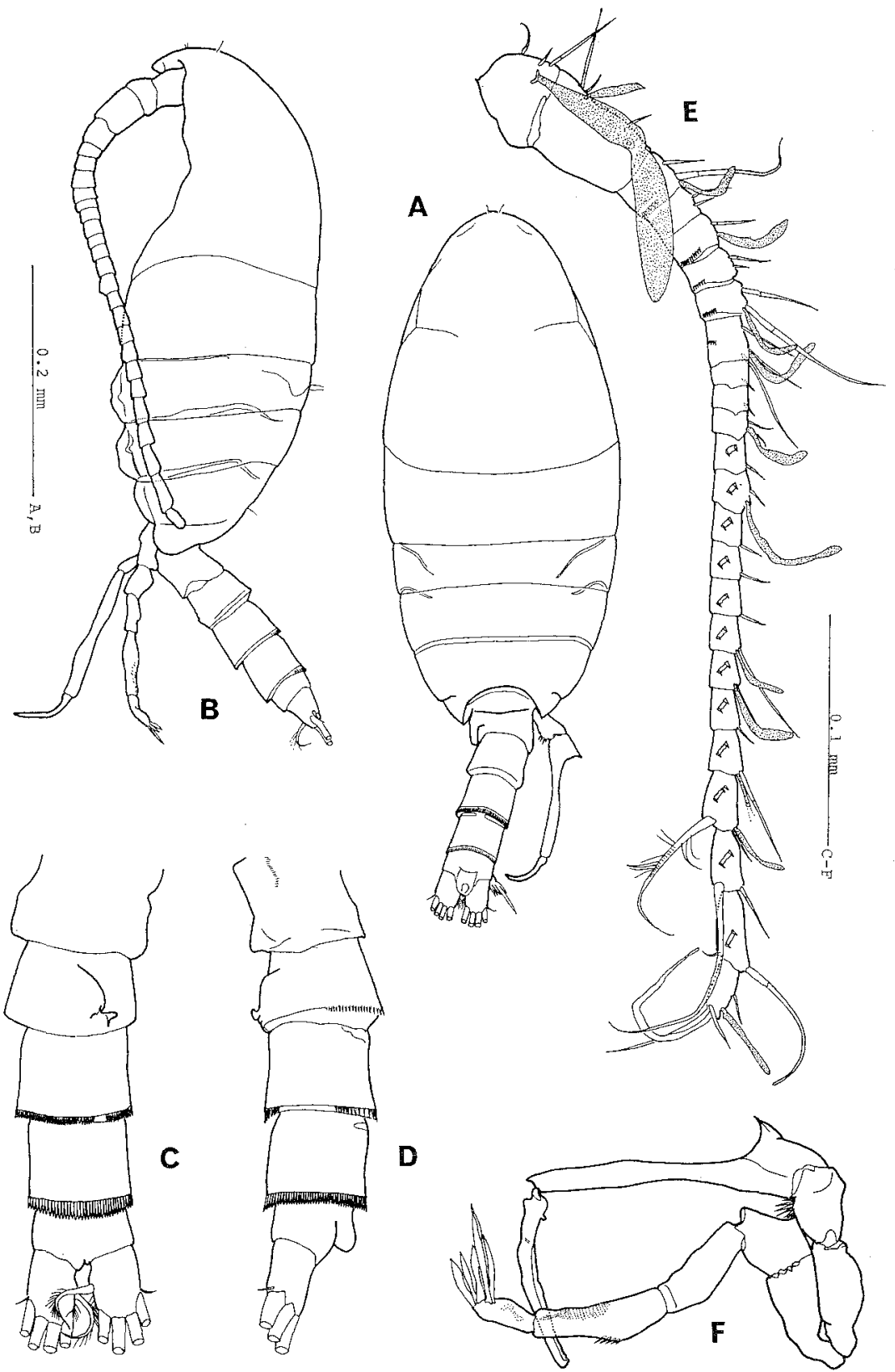

Fig. 3. Stephos pacificus n. sp. Male (paratype No. 1). A. Habitus, dorsal view; B. Habitus, lateral view; C. Urosome, ventral view; D. Urosome, lateral view; E. Antennule; F. Leg 5, anterior face. 
Variation. Number and position of spinules on the surface of legs are more or less variable between right and left legs and between individuals.

Remarks. The female of the present new species is readily distinguished from previously described congeneric species by (1) the genital segment produced ventrally, (2) the shape of gnathal lobe of the mandible, (3) the presence of rows of minute spinules of legs 1 to 4, and (4) the shape of leg 5. The leg 5 of the female of $S$. scotti Sars, 1903 is similar to that of this new species, but inner distal margin of the terminal segment is not serrated. In the male the new species is easily distinguished from other species by (1) the shape of asymmetrical genital segment, (2) the posteroventral process of 2 nd urosomal segment, and (3) the shape of leg 5 ; in particular, terminal and subterminal lamellar spines of the terminal segment of the left leg. The leg 5 of the male of $S$. pentacanthos Chen et Zhang, 1965 is similar to that of the new species, but is different from the latter as follows: the absence of marginal spinules on right 2 nd segment; left 3rd segment longer than 4th one; left 3rd segment without a spinular row on the outer margin and a patch of very minute spinules near the distal inner margin; the absence of five lamellar spines on the left terminal segment.

The specific name pacificus was named after the first record of occurrence of Stephos on the Pacific coast of Japan.

A note on the in situ feeding habits of Stephos pacificus

The adults were collected at a depth of less than $1 \mathrm{~m}$ on 3 December, 1986.

Table 2. Gut contents of the adults of Stephos pacificus n. sp. collected at a depth of less than $1 \mathrm{~m}$ on 3 December, 1986.

\begin{tabular}{lc}
\hline \hline Food items & Largest dimension $(\mu \mathrm{m})$ \\
\hline Naked ciliates & - \\
Coelenterates (nematocysts) & - \\
Nematodes & - \\
Rotifers & \\
Copepod nauplii & $9-23$ \\
Crustacean fragments & - \\
Diatoms & - \\
$\quad$ Thalassiosira spp. & $17-27$ \\
$\quad$ Melosira sp. & $10-21$ \\
$\quad$ Chaetoceros spp. & $7-46$ \\
$\quad$ Cocconeis spp. & $17-23$ \\
$\quad$ unidentified pennate diatoms & \\
Unidentified dinoflagellates & - \\
Silicoflagellates & - \\
$\quad$ Dictyocha fibula & - \\
Cysts or eggs ? & - \\
Bacteria? & \\
\hline
\end{tabular}




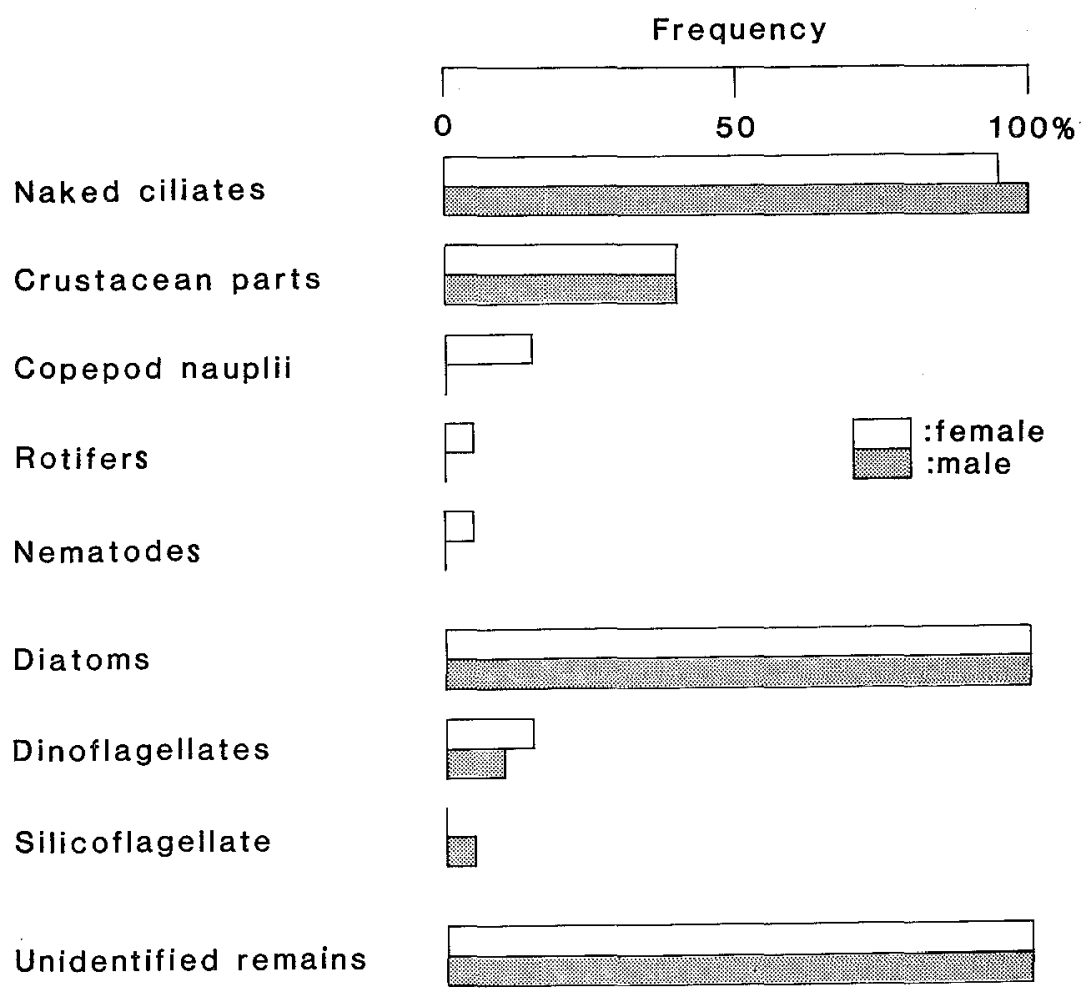

Fig. 4. The frequency of occurrence of food items in the guts of the adults of Stephos pacificus n. sp.

Diets were analyzed by LM observation of 20 guts of each sex. Food items and their percentage frequency of occurrence in the guts are shown in Table 2 and Fig. 4, respectively. Percentage frequency of occurrence is the percentage of guts containing a food item relative to the total number of the guts of xach sex. The frequencies of both sexes are significantly concordant with each other (Kendall's concordance test, $\mathrm{P}<0.05$ ).

The most characteristic feature of the feeding habits is that epibenthic organisms such as naked ciliates, nematodes and pennate diatoms were fed together with pelagic organisms (e.g., centric diatoms). The main foods were diatoms and naked ciliates; diatoms were found in all of the guts $(100 \%)$, and naked ciliates were also frequently detected (female: 95\%; male: 100\%). Crustacean fragments and copepod nauplii occurred in less than $40 \%$. Other organisms such as coelenterates, nematodes, rotifers, dinoflagellates, and silicoflagellates were less frequently found. Unidentified remains were also detected in all the guts; they may have been derived from detritus, sediment particles, and contents of prey organisms.

Both epibenthic pennate diatoms such as Nitzschia (Fig. 5-E) and Cocconeis (Fig. 5-F) and pelagic centric ones such as Thalassiosira (Fig. 5-D, E), Chaetoceros (Fig. 5-F) and Melosira were detected in the guts. The size range of the superficially intact diatoms found in the guts was $7-46 \mu \mathrm{m}$ in largest dimension. These diatoms 


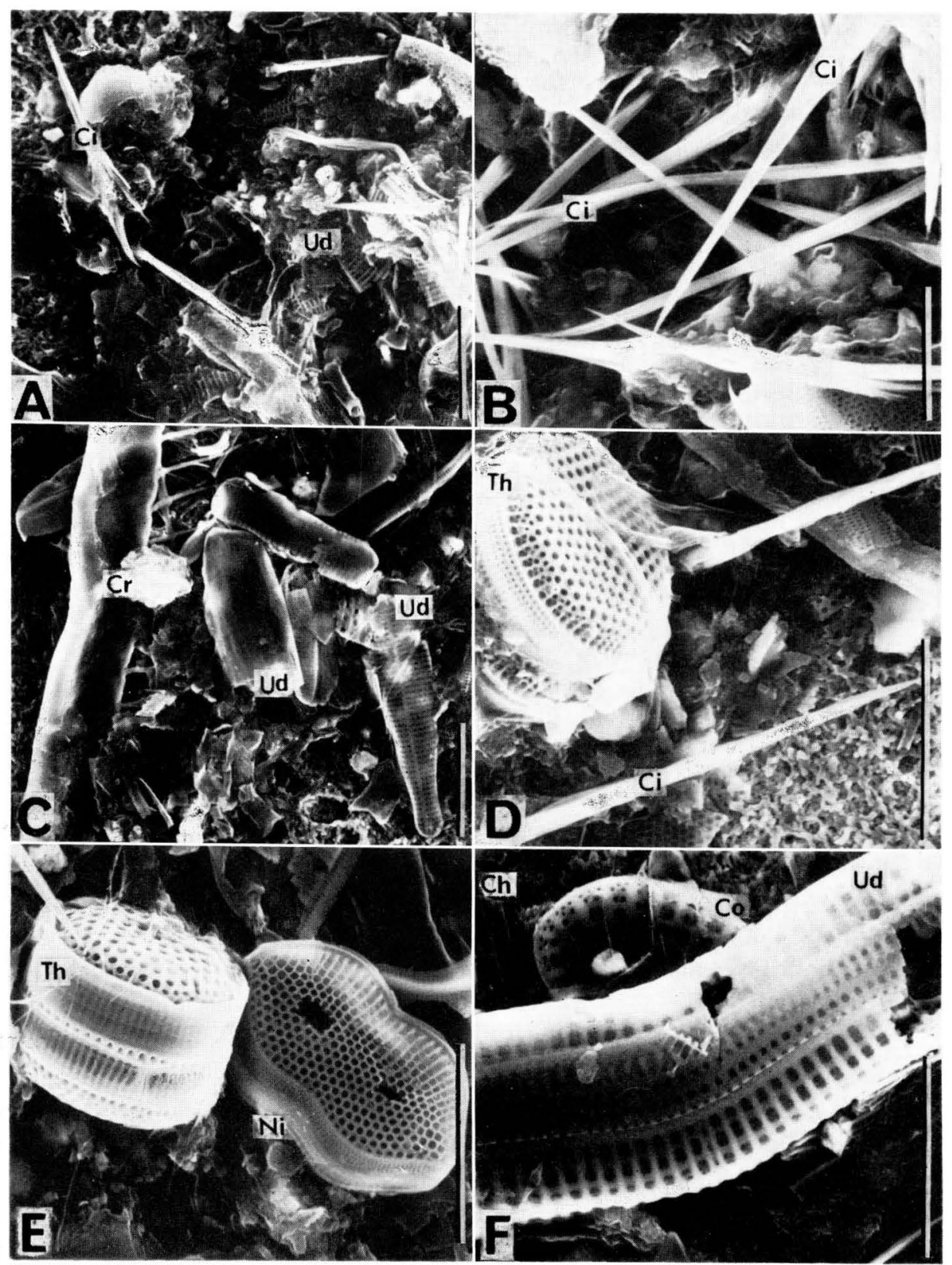

Fig. 5. Food organisms found in the guts of Stephos pacificus n. sp. A. Cilia of hypotrichid ciliates (Ci), unidentified pennate diatom (Ud); B. Cilia of hypotrichid ciliates (Ci); C. Crustacean seta (Cr), unidentified pennate diatoms (Ud); D. Cilia of hypotrichid ciliates (Ci), Thalassiosira (Th); E. Thalassiosira (Th), Nitzschia (Ni); F. Cocconeis (Co), Chaetoceros (Ch), unidentified pennate diatom (Ud). Scale bars of A \& $\mathrm{C}-\mathrm{F}=10 \mu \mathrm{m}$; $B=5 \mu \mathrm{m}$. 
may not have been macerated by the mandibular cutting edges of the copepods.

The cilia usually of $10-30 \mu \mathrm{m}$ detected in almost all the guts (Fig. 5-A, B, D) appear to be cirri or membranelles of hypotrichids (Kosaka, personal communication). As the naked ciliates such as hypotrichids and heterotrichids are extremely abundant on sediments (Fenchel \& Jansson, 1966), they might have been fed on oppotunistically by Stephos.

We observed living individuals swimming in dishes with the flat bottom. during daytime. The copepods swam within $4 \mathrm{~mm}$ above the bottom and rarely moved upwards. The copepods were continuously swimming very fast using the antennae and mandibular palps usually with the left side of the bodies parallel to the bottom. This swimming behavior may enable them to feed on both epibenthic and pelagic organisms.

\section{Stephos robustus n. sp.}

(Figs 6-9)

Materials examined. A dissected adult female was designated as the holotype. An adult female and two males dissected were designated as paratypes. The type specimens are deposited in the Seto Marine Biological Laboratory of Kyoto University.

Type locality: Tanabe Bay. The holotype (23-III-1983, night, $6.0 \mathrm{~m}$ in depth). Paratypes (female: 23-II-1983, night, $5.8 \mathrm{~m}$ in depth; males: No. 1:23-II-1983, night, $5.8 \mathrm{~m}$ in depth; No. 2: 26-VI-1983, night, $7.7 \mathrm{~m}$ in depth).

Female (holotype). Body (Fig. 6-A, B): $1.01 \mathrm{~mm}$ in length. Prosome robust. Cephalosome separated from 1st metasomal segment; 4th metasomal segment partly fused with 5th segment. The surface of prosome and urosome covered with patches of very fine spinules; the posterolateral corners of prosome slightly asymmetrical: the right side is more elongated than the left one; left side bilobed, while right side roundly lobated. Urosome (Fig. 6-C, D, E) 4-segmented; genital segment asymmetrical, with lateral swellings on both sides, and a small dorsal boss in the middle; anterior margin of genital operculum fringed with a row of spinules; a transverse row of spinules present on each lateral side; left distal margin bearing a minute spinular row ventrolaterally. The spermatophore attached to the genital segment is very slender, about twice as long as urosome. Second and 3rd urosomal segments subequal in length, finely striated along the distal margin. Caudal ramus slightly longer than broad. Antennule (Fig. 7-A) 24-segmented; 1st and 2nd segments partly fused; 1st segment with two rows of spinules; 5 th to 9 th segments bearing one or two transverse rows of fine spinules; 12th to 23rd segments each with lamellous plate as in S. pacificus. Antenna (Fig. 7-B): 2nd exopod segment carrying a curved row of minute spinules; proximal endopod segment with a patch of minute spinules near the distal end; apical segment of endopod with elongated outer lobe. Mandible (Fig. 7-C, D); gnathal lobe with 8 teeth, spinulose seta on edge and minute spinules on surface; exopod 5-segmented. Maxillule (Fig. 7-E): gnathobase with 6 spines and 7 setae; basipod 2 with spinules near base of exopod; 
exopod bearing two rows of spinules on surface. Maxilla (Fig. 7-F): basipod with 6 lobes; Ist to 6 th lobes bearing 6,3,3,3,4 and 1 setae, respectively; endopod 3-segmented, bearing 5 setae in all. Maxilliped (Fig. 8-A) elongated.
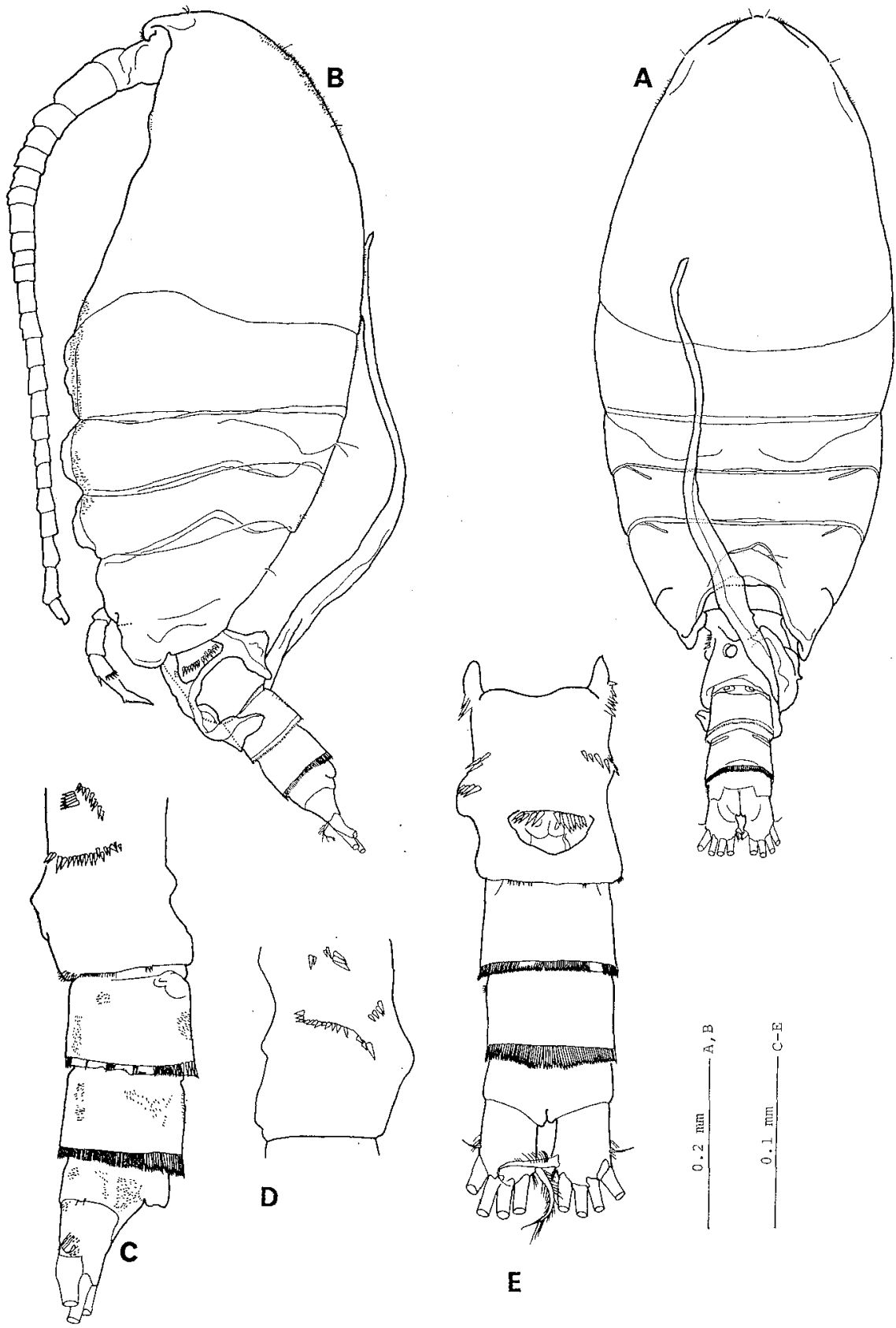

Fig. 6. Stephos robustus n. sp. Female (holotype). A. Habitus, dorsal view; B. Habitus, lateral view; C. Urosome, lateral view from left side; D. Genital segment, lateral view from right side: E. Urosome, ventral view. 
Legs 1 to 4 with the same segmentation, spinulation and setation as in S. pacificus (see Table 1). Leg 1 (Fig. 8-B): basipod 2 bearing a row of minute processes in the middle of distal end. Leg 2 (Fig. 8-C): basipod 1 bearing spinules on outer margin and basipod 2 bearing minute spinules on inner distal end; apical segment of endopod carrying spinules and ending into a prominent process. Leg 3 (Fig. 8-D): spinules present on outer margin of basipod 1 , and fine spinules on inner distal

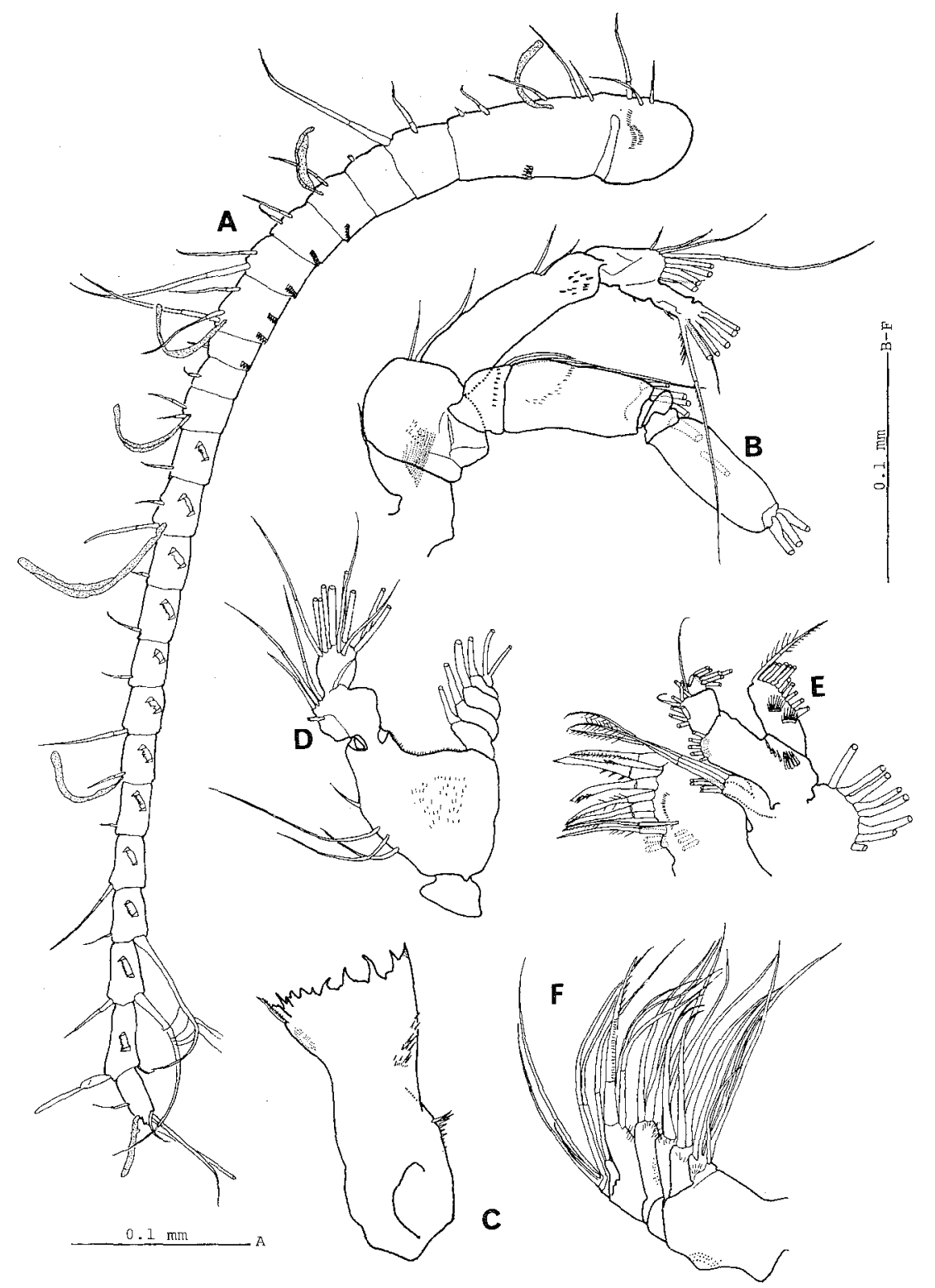

Fig. 7. Stephos robustus n. sp. Female (holotype). A. Antennule; B. Antenna; C. Mandibular gnathobase; D. Mandibular palp; E. Maxillule; F. Maxilla. 
end of basipod 2. Leg 4 (Fig. 8-E) much slenderer than first three legs. Leg 5 (Fig. 8-F) symmetrical, uniramous, 3-segmented; medially fused 1st segments without armatures; 2nd segment widening distally with very minute spinules on surface; terminal segment with a transverse row of spinules across near the middle, a patch of spinules on the middle inner margin and an incurved setula; distal part of terminal segment tapering distally, curved inwards and carrying two rows of fine

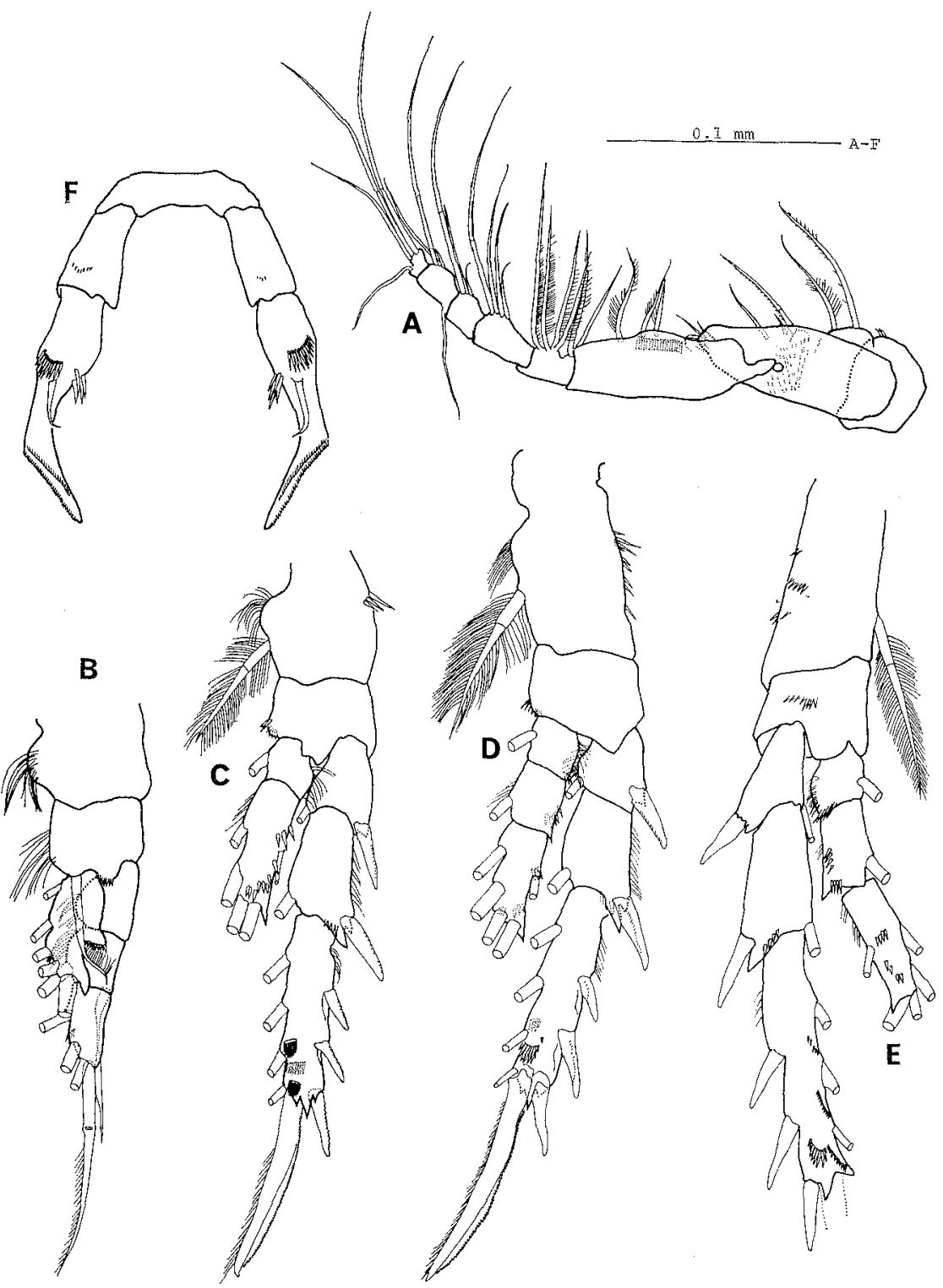

Fig. 8. Stephos robustus n. sp. Female (holotype). A. Maxilliped; B. Leg 1, anterior face; C. Leg 2, anterior face; D. Leg 3, posterior face; E. Leg 4, anterior face; F. Leg 5, posterior face. 
spiniform processes.

Male (paratypes). Body (paratype No. 2) (Fig. 9-A) $0.91 \mathrm{~mm}$ in length, robust as in female. Urosome (paratype No. 2) (Fig. 9-B) 5-segmented, 2nd segment produced posteroventrally into a finger-like process. Antennular aesthetascs

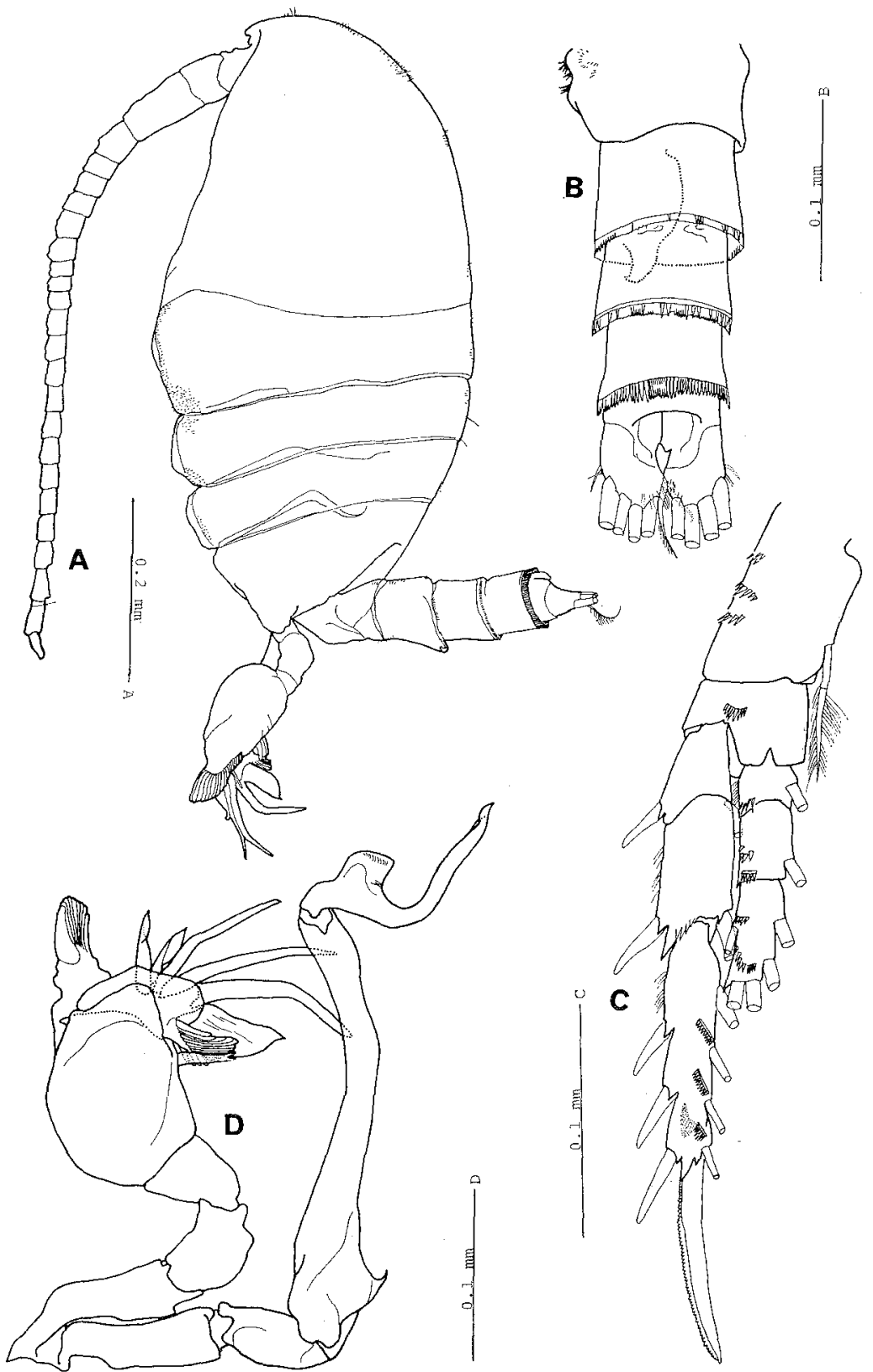

Fig. 9. Stephos robustus n. sp. Male (A, B: paratype No. 2; C, D: paratype No. 1). A. Habitus, lateral view; B. Urosome, dorsal view; C. Leg 4, anterior face; D, Leg 5, anterior face. 
thicker than in female. Antenna, mandible, maxillule, maxilla, maxilliped and legs 1-4 similar to counterparts in female; Leg 4 (paratype No. 1) (Fig. 9-G) as in the holotype in structure. Leg 5 (paratype No. 1) (Fig. 9-D) is complex with 5-segmented left leg. Right leg: 3rd segment very elongated, slightly curved inwards, having flattened proximal part bearing a short acute process near the base; 4th segment with basal lamellar part and extreme cylindrical part. Left leg consisting of 5 segments; penultimate segment massive, with a bifurcated large spine on inner margin and complex cristate formation on outer distal margin; terminal segment with five large spines of unequal lengths on distal margin, one lamellar plate on tip, and a comb-like process near the plate.

Variation. Spinulation of the legs is more or less variable between individuals and between the sexes.

Remarks. The present species is easily distinguished from the other species of the genus by the asymmetrical genital segments of both sexes with numerous fine spinules, a posteroventral finger-like process of male 2nd urosomal segment, and the shape of legs 5 of both sexes.

\section{Acknowledgements}

We are very grateful to Prof. T. Onbé and Dr. K. Venkateswaran of Hiroshima University for reading the manuscript and criticism, and Dr. T. Itô of Kyoto University for his help in our sampling. Thanks are due to Dr. T. Kosaka of Hiroshima University for his authoritative information on preyed ciliates by Stephos and Mr. Y.-H. Yoo of Hiroshima University for his identification of prey diatoms of the copepods. This work is partly supported by a grant-in-aid (Project No. 61760164) from the Ministry of Education, Science and Culture of Japan to the senior author (SO).

\section{References}

Chen, Q.-C. \& S.-Z. Zhang. 1965. The planktonic copepods of the Yellow Sea and the East China Sea I. Calanoida. Stud. Mar. Sinica, 7: 20-131, 53 pls.

Fenchel, T. \& B.-O. Jansson. 1966. On the vertical distribution of the microfauna in the sediments of a brackish beach. Ophelia, 3: 161-171.

Ohtsuka, S. 1984. Calanoid copepods collected from the near-bottom in Tanabe Bay on the Pacific coast of the Middle Honshu, Japan. I. Arietellidae. Publ. Seto Mar. Biol. Lab., 29: 359-365. 1985. Calanoid copepods collected from the near-bottom in Tanabe Bay on the Pacific coast of the Middle Honshu, Japan. II. Arietellidae (cont.). Ibid., 30: 287-306.

$\longrightarrow$ A. Fleminger \& T. Onbé. 1987. A new species of Pontella (Copepoda: Calanoida) from the Inland Sea of Japan with notes on its feeding habits and related species. J. Crust. Biol., 7 : $554-571$.

Sars, G.O. 1903. Copepoda. Calanoida. An account of Crustacea of Norway, 4. 171 pp., 108 pls. Bergen Museum, Bergen. 